\title{
Assessing operational risk while using the logic of the included middle
}

\author{
Răzvan TUDOR \\ ASE București, România \\ razvantudor@me.com
}

\begin{abstract}
From the Solvency II perspective, the capital requirement for operational risk is based on the application of a standard formula. The limitation imposed by this approach as well as the definition of operational risk by establishing certain types of activities (i.e. internal processes, people, systems, etc.) as generating causes does not allow, at least for the time being, the establishment of an effective way of managing the operational risk regardless of the type of strategy chosen. Any human operator involved in the risk identification and evaluation processes, within most of the organizations, would use the logic of the included middle based on Boolean binary values (i.e. true/false, 1/0, etc.). This article attempts to logically analyze the methodological impact that would result from using a logic of the included middle which accepts that an identified operational risk and an unidentified operational risk may coexist at the same time, in a risk profile, provided that the identified one is actual and the unidentified one is potential, reciprocal and alternative but never up to the 100\% limit. The included middle in this approach is the transition state, which is perfectly possible in terms of defining the topological properties of the time in which the identified operational risks analyzed are assessed. The novelty of this approach is based on the fact that the logic of the included middle, which we include in research as a concept and as a tool, was one of the nudging factors that underpinned the development of the wave mechanics (e.g. Schrodinger's Cat Paradox) and some of the quantum physics theories later, and its use has never been tested in risk management.
\end{abstract}

Keywords: Operational risk assessment, insurance, Solvency II, logic of the included middle, quantum logic.

\section{Introduction}

The identification, assessment and management of operational risk in the insurance sector at the European Union level began to be defined a few years ago through the Solvency II Directive 138/2009 and the Delegated Regulation 35/2015.

Subsequent clarifications to primary legislation through Guidelines issued by EIOPA (in this case the ORSA Guide) and through local regulations in Romania, ASF Norm 1/2019 and Norma ASF 4/2018, contributed to a nuance of good practice in the field imposing a series of specific compliance and reporting requirements.

In this article we plan to drawn the attention towards an intrinsic limitation from the point of view of the logical system used in identifying and assessing operational risk and to propose a new logical thinking the assessment processes are to be based on.

\section{Literature review}

Law $237 / 2015$ on the authorization and supervision of the insurance and reinsurance activity which aimed at transposing the Solvency II Directive in Romania establishes the definition of operational risk in the field it regulates as follows: "operational risk is the risk of loss due to inadequate internal processes or malfunctions, personnel or systems or 
external events; "If this definition determines how an operational risk materializes, i.e. the recording of losses, in the spirit of the reference document of the Institute of Operational Risk IOR) about RCSA (Risk Control Self-Assessment) "the term "risk" is generally defined as something that has not yet caused a direct operational problem for the firm, however there remains some degree of uncertainty about future outcomes."

A first distinction we can make is that a causal relationship has yet to be considered starting from the general definition of risk and particularly of operational risk, meaning that some intrinsic or inherent potential exposure, as the IOR states in the RCSA, along with internal and/or external causes, forms the basis for the possibility of "events or issues" occurrence. A second distinction is the difference between the risk and the event per se.

Still considering the legislation, a taxonomic clarification states in this industry that "operational risk includes legal risk but excludes reputational and decisional risk."

A more detailed definition of what can be described as a part of the operational risk, is provided by Standard 4/2018 of the ASF, which states that: "the risk of information technology (IT) (subcomponent of operational risk) that refers to the present or future risk of negative impact, on the one hand, of the profits and capital of the entities or investors, participants or policyholders, on the other hand, due to the inadequacy of IT strategy and policies, information technology and its processing, in terms of the capacity of management, integrity, controllability and continuity or inappropriate use of technology information;

Concerning the IT Operational Risk Register a detailed analysis of the same type of methodology, as well as the related limitations, valid in the context of previous regulation, Norm 6/2015 of the ASF, was previously made by Tudor, R., \& Badea, D. (2017). One of the topics that was not addressed was that of the way in which the operational risk, particularly that of IT systems in insurance, can be identified or assessed efficiently and effectively.

Best practices starting with ISO 31000 and ISO 27001 standards establish distinct methodologies (based on questionnaires, interviews, workshops facilitated) or industrylevel reference databases as a way of assessing risks. Similarly, the IOR guideline once again points to the fact that "the techniques and disciplines of inherent risk estimation can be extremely subjective and difficult to quantify." This difficulty in practice has been overcome so far due to the punitive nature of risk regulations (Solvency, Basel), or the resilience requirements assumed by an undertaking.

An entire literature Kahneman, D., \& Tversky, A. (2000) and a self-contained behavioural economics discipline focused on the subjective nature of these measurements and the factors that can lead to unconscious errors of risk assessment or management.

The perceptions of those assessing a risk, from the perspective of previous experience, but also from the perspective of possible observations to be made on a measurement, especially in the case of extreme events, were analyzed by Slovic, P. \& Weber, E. (2002) so that "Psychometric studies have demonstrated that each hazard has a unique pattern of qualities that appear to be related to its perceived risk.". Slovic, P. \& Weber, E. (2002) indicates that the processing of risk information occurs at an individual level in two ways: „one processing system is evolutionarily older, fast, mostly automatic, and hence not very accessible to conscious awareness and control. It works by way of similarity and associations, including emotions, often serving as an "early-warning" system. The other processing system works by algorithms and rules, including those specified by normative models of judgment 
and decision making (i.e., the probability calculus, Bayesian updating, formal logic), but is slower, effortful, and requires awareness and conscious control."

The concern to be able to predict how future risks will materialize either in terms of probability and impact, either from a different metric scale perspective is influenced by principles that works at the elementary particles level. More than 80 years ago, an observation that marked a turning point in the evolution of contemporary physics, Heisenberg's principle of uncertainty and which formed the basis of quantum logic, stipulated that "even a complete mathematical description of a physical G system does not generally predict with certainty the result of an experiment on $G$, and that in particular one can never predict with certainty both the position and the momentum of G. "Birkhoff, G., \& von Neumann, J. (1936).

To this the principle of Non-commutativity of Observations through which "most pairs of observations are incompatible, and cannot be made on G simultaneously" is added.

This principle became famous in the history of quantum physics through the experiment of Schrödinger's cat, a cat that was enclosed in a box with a radioactive metal and for which "Schrödinger insisted, the cat that's linked to the atom must likewise be described, in quantum language, as equal parts dead cat and live cat." Lindley, D. (2008). Quantum physics specialty literature, Cushing, JT (2007), becomes relevant in terms of risk management as long as the assessed processes or actions can be assimilated to systems that are described in physics theory. Although quantum physics has not developed studies on the description of systems in terms of risks, studies that address the laws governing causality and the manner observations are made in order to analyze a system have been yet conducted. Transferring these laws and principles into the risk management field involves transdisciplinarity that, before being mathematically analyzed, should be logically grounded.

Paul Dirac was thus the one who attempted to demonstrate that only in undisturbed systems we can speak of causality that can be demonstrated in terms of effects, while Heisenberg W. argued that the position and impulse of a particles set cannot be simultaneously measured precisely. Bohr also mentioned in his works that a separation between observation and her observer cannot be made and apparently, there is no deterministic method in order to predict the future trajectory of an electron. Even though the last hundred years since these discoveries have brought forth other perspectives such as that of Professor Truscott, "A future event causes the photon to decide its past." Morgan, S. (2015)

Further turning and evolution of quantum physics research at the beginning of the twentieth century was possible due to the fact that logical thinking considered exceeding the boundaries of the logic of the included middle. These are the fundamental axioms of the classical logic of the excluded middle on which all mechanical and thermodynamic physics were based until the first equations becoming, in this context, contradictory:

1. The axiom of identity: $\mathrm{A}$ is (or $=$ ) $\mathrm{A}$.

2. The axiom of non-contradiction: $A$ is not (or $\neq$ ) non-A.

3. The axiom of the excluded middle: there exists no third term ' $\mathrm{T}$ ' ( $\mathrm{T}$ ' from third)

that is at the same time A and non-A." Brenner, J. E. (2010)

The research and the literature published on the logical contradictions involved in using this system in mathematics or quantum physics have led to the emergence of situations where certain results can no longer be declared either true or false. For this reason, "logicians were 
forced to introduce other values for sentences than true-false dyads" resulting in polyvalent logic. Dumitriu, A., \& Stíhi, T. (1971).

The importance of the type of logic used in risk assessment comes from countless situations where significant risks (which may have a significant impact) are not taken into account even in simple forms of registration (risk sheets or risk register) because the possibility or probability of materialization is not understood, accepted or in short: it is not perceived as true.

\section{Methodology}

Operational risk is actually intrinsic to each operation. What becomes extremely valuable in the process of identification, assessment and analysis results from the ability to predict the materialization of a risk and the effectiveness of the related preparation for its mitigation. The current outlook of risk management manner is based on a causal approach.

Cause Cz. applied to the event Ev. generates a consequence/effect Cs.. Theories studied and analyzed in Tudor, R., \& Badea, D. (2017) and Badea D., Tudor R., (2016) on the tools used in the operational risk assessment across the causal chain can be consulted.

For the purpose of this article we will use one of the examples proposed by the regulator of the Romanian insurance market, namely: data corruption in the information technology category, as it was recorded in the IT operational risk register in the Norm 4/2018 methodology.

Fig. 1. Example of Risk Register proposed by the Romanian regulator

\begin{tabular}{|c|c|c|c|c|c|c|c|c|}
\hline $\begin{array}{l}\text { Categorie Resursă/ } \\
\text { Activitate }\end{array}$ & $\begin{array}{l}\text { Denumire sistem } \\
\text { informatic }\end{array}$ & $\begin{array}{l}\text { Valoare } \\
\text { resursa / } \\
\text { activitate }\end{array}$ & Risc (descriere / amenintare) & Vulnerabilitate (factori de risc) & $\begin{array}{c}\text { Valoare } \\
\text { probabilitate }\end{array}$ & $\begin{array}{c}\text { Valoare } \\
\text { vulnerabilitate }\end{array}$ & Valoare risc & $\begin{array}{l}\text { Masuri de } \\
\text { control al } \\
\text { riscului }\end{array}$ \\
\hline \multicolumn{9}{|c|}{ Tehnologia informatiei } \\
\hline Personal si sisteme IT & $\begin{array}{l}\text { Statie de lucru / bază de } \\
\text { date / sisteme informatice } \\
\text { importante }\end{array}$ & 2 & \begin{tabular}{|c|} 
lipsa unei delimitări clare între rolurile \\
persoanelor care \\
acceseaža/administrează/dezvoltă \\
sistemele informatice
\end{tabular} & Proceduri de lucru neclare sau nepuse in aplicare & 1 & 3 & 6 & Anexa 1 \\
\hline Personal si sisteme IT & $\begin{array}{l}\text { Stație de lucru / bază de } \\
\text { date / sisteme informatice } \\
\text { importante }\end{array}$ & 2 & $\begin{array}{c}\text { conflict de interese între personalul } \\
\text { care dezvoltă și cel care administrează } \\
\text { sistemele informatice ori între } \\
\text { utilizatorii acestora }\end{array}$ & $\begin{array}{l}\text { Inexistenta unor proceduri privind gestiunea } \\
\text { conflictelor de interesa sau nepunerea in aplicare a } \\
\text { acesteia }\end{array}$ & 1 & 3 & 6 & Anexa 1 \\
\hline Personal si sisteme IT & $\begin{array}{c}\text { Statie de lucru / bază de } \\
\text { date / sisteme informatice } \\
\text { importante }\end{array}$ & 2 & $\begin{array}{c}\text { cunostinte, experiență și pregătire } \\
\text { insuficientă a personalului care } \\
\text { utilizează sau deservește sistemele } \\
\text { informatice }\end{array}$ & $\begin{array}{l}\text { Buget de training insuficient. Lipsa implicarii } \\
\text { managementului in acest aspect. }\end{array}$ & 1 & 3 & 6 & Anexa 1 \\
\hline Personal si sisteme IT & $\begin{array}{l}\text { Stație de lucru / bază de } \\
\text { date / sisteme informatice } \\
\text { importante }\end{array}$ & 2 & alterarea datelor & $\begin{array}{c}\begin{array}{c}\text { Alterarea datelor din sistemele informatice, fara } \\
\text { osibilitatea identificarii autorului si a informatiilor } \\
\text { initiale }\end{array}\end{array}$ & 1 & 3 & 6 & Anexa 1 \\
\hline Personal si sisteme IT & $\begin{array}{l}\text { Stație de lucru / bază de } \\
\text { date / sisteme informatice } \\
\text { importante }\end{array}$ & 2 & $\begin{array}{c}\text { nerespectarea proceselor, procedurilor } \\
\text { sau a instrucțiunilor de lucru }\end{array}$ & $\begin{array}{l}\text { Procese organizatorice, proceduri si instructiuni de } \\
\text { lucru neimplementate sau inexistente }\end{array}$ & 2 & 3 & 7 & Anexa 1 \\
\hline Personal si sisteme IT & $\begin{array}{l}\text { Stație de lucru / bază de } \\
\text { date / sisteme informatice } \\
\text { importante }\end{array}$ & 2 & $\begin{array}{c}\text { Lipsă de comunicare şi cooperare între } \\
\text { angajați }\end{array}$ & $\begin{array}{l}\text { Necomunicarea la timp a unor informatii critice de la } \\
\text { un departament catre altul }\end{array}$ & 1 & 3 & 6 & Anexa 1 \\
\hline
\end{tabular}

Source: ASF Norm 4/2018, Methodology

The risk is: data corruption.

Vulnerability: Alteration of data from computer systems, without the possibility of identifying the author and the initial information.

Note: This risk is not included in the Annex 1of the cited regulation, which includes control measures for the risks in the register.

Assessing the risk through the classical perspective, the following information results:

I1. The probability that data is corrupted is 1 , therefore low.

I2. The value assigned to the resource is 2 : average 
I.3 The vulnerability value is 3 : maximum.

I4. There is a presumption in the description of vulnerability, that a cause would be a person, the "author", and a consequence would be the non-recovery of "initial data"

15. The value of the risk is 6 (a value that can be considered as average)

Based on the information available for the described vulnerability, we have the following sentences with true or not true value:

PICBE |

A) Data is corrupted $=1$

$\neg$ A) Data is not corrupted $=0$

B) The author is identified $=1$

$\neg B) \quad$ The author is not identified $=0$

C) Initial information are recovered $=1$

$\neg C)$ Initial information are not recovered $=0$

Following the binary principles of a Boolean algebra we have the following possible situations with the following results:

Tabel 1: Boolean algebra applied to the situation assessed

\begin{tabular}{|c|c|c|c|}
\hline A & B & C & $\mathrm{f}(\mathrm{A}, \mathrm{B}, \mathrm{C})$ \\
\hline 0 & 0 & 0 & 0 \\
\hline 0 & 0 & 1 & 0 \\
\hline 0 & 1 & 0 & 1 \\
\hline 0 & 1 & 1 & 0 \\
\hline 1 & 0 & 0 & 1 \\
\hline 1 & 0 & 1 & 1 \\
\hline 1 & 1 & 0 & \multicolumn{2}{c|}{ Source: Potorac, A. D. (2002) } \\
\hline 1 & 1 & 1 & \multicolumn{2}{c}{} \\
\hline
\end{tabular}

Tabel 2: Simplified version of a Karnaugh diagram with three variables

\begin{tabular}{|c|c|c|c|c|}
\hline $\mathrm{A} / \mathrm{BC}$ & 00 & 01 & 11 & 10 \\
\hline 0 & 0 & 0 & $\mathbf{1}$ & 0 \\
\hline 1 & 0 & $\mathbf{1}$ & $\mathbf{1}$ & $\mathbf{1}$ \\
\hline
\end{tabular}

Hence the four situations that are possible and should be analysed in terms of probability of realization:

$\mathbf{f}(\mathbf{0 , 1}, \mathbf{1})=\neg \mathbf{A B C}-$ the data are not corrupted, the author is identified, the initial information is recovered

$\mathbf{f}(\mathbf{1}, \mathbf{0 1})=\mathbf{A} \neg \mathbf{B C}$ - the data are corrupted, the author is not identified, the initial information is recovered

$\mathbf{f}(\mathbf{1}, \mathbf{1}, \mathbf{1})=\mathbf{A B C}$ - the data are corrupted, the author is identified, the initial information is recovered

$\mathbf{f}(\mathbf{1}, \mathbf{1}, \mathbf{0})=\mathbf{A B} \neg \mathbf{C}$ - the data are corrupted, the author is identified, the initial information is not recovered 
Lack of historical data or contextual information could lead to the assignment of equal probabilities for each of the four alternatives.

This binary approach, circumscribed to a classical logic, does not allow in this multitude of possible situations to accept that the data may at the same time be corrupted but may at the same time be uncorrupted for example: $(A \neq \neg A)$. This contradictory aspect violates precisely the principle of the excluded middle, and yet the situation may be perfectly valid in a reality in which these measurements are made empirically. The constraint imposed by the principle of the included middle also has an atypical dimension because the corruption of the data is equally independent of the temporal causality implicitly suggested in the description of vulnerability: the author corrupts the data that cannot be recovered. It may also be true to say that the data has been corrupted by attempting to occasionally verify it in the absence of information about the authors who would have done so.

Data corruption becomes so a measurable risk indicator, independent of the cause (author) and the effect (recovery of information) as listed in Vulnerability. Moreover, including the measurement of this risk indicator does not transmit relevant information about the whole process, nor does the monitoring of cause or effect lead to a better risk assessment as a whole.

Analysing the information available in a Boolean binary logic, which does not result from this risk register, there are also other information, that might have been useful in terms of operational risk assessment and management, as for example:

- What are all the causes that stand at the root of this risk, for example: unauthorized access to the network, malicious access, intentional or unintentional virus application, proprietary application errors, voltage fluctuations, other physical incidents that could impact the support on which the data is stored, and the list can continue?

- When do we know if this risk materialized?

- How do we know if and what is the cause of this risk?

- How do we measure it effectively: from the amount of corrupted data, the actual impact in business of missing these data in the correct form?

\section{Dynamic logic of contradiction}

Use of binary logic in validating possibilities, potentialities (such as risks as compared to the events) only suppresses sources of primary information from the records and the documentations of a risk. In fact, if logic does not coincide with the perceived reality, in the sense that a risk may or may not materialize in a future timeframe, the problem as Reichenbach, M. (1971) noticed, does not lie in the perception of reality but in the logic used in its description.

For this purpose and in order to overcome this deficiency, we intend to analyse the extent to which the dynamic logic of the contradictory Lupascu, Ş, Noica, C., et all. (1982) allows the assumption of the fundamental contradictions: "Any phenomenon, element or logical event, as well as the judgment that judges it, the sentence that expresses it or the sign that symbolizes it: as for example, $e$ must always be associated, structurally and functionally, to an anti-phenomenon or anti-element, or logical ante-event, and thus a judgement on, a sentence, or a contradictory sign: non-e or $\bar{e}$; and in such a way that $e$ or $\bar{e}$ can never be more 
than potentiated by actualizing $e$ or $\bar{e}$, and not making them disappear, so that $e$ or $\bar{e}$ are sufficient to themselves in an interdependency and hence a rigorous non-contradiction.

Therefore, the axioms of classical logic, according to Brenner, JE (2010), could be reformulated by Lupascu, as follows:

1. (Physical) Non-Identity: There is no $e$ at a given time that is identical to $e$ at another time.

PICBE |

2. Conditional Contradiction: $e$ and non-e both exist at the same time, but only in the sense that when $e$ is actual, non- $e$ is potential, reciprocally and alternatively, but never to the limit of $100 \%$.

3. Included Middle: An included or additional third element or T-state ('T' for 'tiers inclus', included third).

An analysis of the classical logic of a case quite simplistically approached in the proposed risk register as an ASF model shows that such a simple risk can be both potential and actual, or in none of these two states. That is, data may or may not be corrupted in the future, they may or may not be corrupted at the time of risk control / measurement, or they may not be corrupted now but become corrupted in the future. All these states cannot be described in a classical logic system. Lupascu, Ş, Noica, C., et all. (1982).

The dynamic logic of contradiction implies the existence of an actual event $\left(\mathrm{e}_{\mathrm{A}}\right)$ that corresponds to an actual non-event $\left(\neg e_{A}\right)$, a potential event (eP) to which a non-potential event ( $\neg$ ep), corresponds, as well as an event in a transition state that is neither actual nor potential $\left(\mathrm{e}_{\mathrm{T}}\right)$ and a non-event $\left(\neg \mathrm{e}_{\mathrm{T}}\right)$. The relationships of such a logic are described in Lupascu, Ş, Noica, C., et all. (1982) as follows:

$$
\begin{aligned}
& \text { е }
\end{aligned}
$$

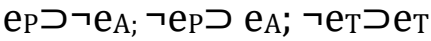

And for contradictory basic conjunctions:

$$
\left.\left.\left.\mathrm{e}_{\mathrm{A}} \times\right\urcorner \mathrm{eP}_{\mathrm{P}}\right\urcorner \mathrm{e}_{\mathrm{A}} \times \mathrm{e}_{\mathrm{P}} \mathrm{e}_{\mathrm{T}} \times\right\urcorner \mathrm{e}_{\mathrm{T}}
$$

For the mentioned postulate of the dynamic logic of contradiction: „Everything given by logic is always described by a logic quantum Q":

$$
\mathrm{Q}=\mathrm{f}\left[\left(\mathrm{e}_{\mathrm{A}} \times \neg \mathrm{e}_{\mathrm{P}}\right) \cup\left(\neg \mathrm{e}_{\mathrm{A}} \times \mathrm{e}_{\mathrm{P}}\right) \cup\left(\mathrm{e}_{\mathrm{T}} \times \neg \mathrm{e}_{\mathrm{T}}\right)\right]=\left(\mathrm{e}_{\mathrm{A}} \supset \neg \mathrm{e}_{\mathrm{P}}\right) \cup\left(\neg \mathrm{e}_{\mathrm{A}} \supset \mathrm{e}_{\mathrm{P}}\right) \cup\left(\mathrm{e}_{\mathrm{T}} \supset \neg \mathrm{e}_{\mathrm{T}}\right)
$$

Where $U$ is the exclusion disjunction.

"When we then find ourselves in the presence of two contradictory phenomena that are at the same level of update or potentiation, we will not only not reduce them to 0 as in the usual logic (or in Aristotle's metaphysical" power "), but we will reduce them to the T state, i.e. we will consider them neither actual nor potential, or more precisely semi-actual or semi-potential, both at the same time and each to one another; mandatorily behind them a potentiality, and in front of them a timeliness since, according to the fundamental postulate of this dynamic logic of contradictory, neither of the two can be independent and absolute, i.e. rigorously actualized or rigorously potentiated "Lupascu, Ş, Noica, C. et all. (1982)

The relationship of truth between events and non-events in classical logic are described in Table 3, while the values taken under the dynamic logic of contradiction are 
described in Table 4, and the matrix of irreducible contradiction and relative noncontradiction are presented in Table 5.

Table 3. The relationship of truth between events and non-events in classical logic

\begin{tabular}{|c|c|}
\hline $\mathbf{e}$ & $\neg \mathbf{e}$ \\
\hline $\mathrm{A}$ & $\mathrm{F}$ \\
\hline $\mathrm{F}$ & $\mathrm{A}$ \\
\hline
\end{tabular}

PICBE |

Source: Lupascu, Ş, Noica, C. et all. (1982)

Table 4. The relationship of truth between events and non-events in dynamic logic of contradiction

\begin{tabular}{|c|c|}
\hline $\mathbf{e}$ & $\neg \mathbf{e}$ \\
\hline $\mathrm{A}$ & $\mathrm{P}$ \\
\hline $\mathrm{T}$ & $\mathrm{T}$ \\
\hline $\mathrm{P}$ & $\mathrm{A}$ \\
\hline
\end{tabular}

Source: Lupascu, Ş, Noica, C. et all. (1982)

Where: $\mathrm{A}=$ actual, $\mathrm{P}=$ potential, $\mathrm{T}=$ transition

Table 5. Matrix of irreducible contradiction and relative non-contradiction

\begin{tabular}{|c|c|c|c|}
\hline $\mathbf{e}$ & $\neg \mathbf{e}$ & $\neg \mathbf{C}$ & $\mathbf{C}$ \\
\hline $\mathrm{A}$ & $\mathrm{P}$ & $\mathrm{A}$ & $\mathrm{P}$ \\
\hline $\mathrm{T}$ & $\mathrm{T}$ & $\mathrm{P}$ & $\mathrm{A}$ \\
\hline $\mathrm{P}$ & $\mathrm{A}$ & $\mathrm{A}$ & $\mathrm{P}$ \\
\hline
\end{tabular}

Source: Lupascu, Ş, Noica, C. et all. (1982)

Where: $\neg \mathrm{C}$ - non-contraction, $\mathrm{C}$ - contradiction

According to the dynamic logic of the contradictory there is [...] a quadruple truth or four possible truths: $\left.V_{(} e_{A}\right), V_{(}\left(e_{A}\right), V_{(}(e), V_{(}(\neg e)$.

In this context, an analysed event can have three states: actual (A), potential (P) and transition (T). According to the explanatory notes in Lupascu, Ş, Noica, C., \& Sporici, V. (1982): the actual could correspond to the present, the potential to the future and $t$ is assimilated to the past.

\section{The order of time or the direction of time?}

Within the context of the three states described by the dynamic logic of contradictory, some observations made by Reichenbach, M. (1971) on the order and direction of time become important:

1. Time goes from the past to the future.

2. The present, which divides the past from the future, is now.

3. The past never comes back.

4. We cannot change the past, but we can change the future.

5. We can have records of the past, but not of the future.

6. The past is determined; the future is undetermined. 
All these observations in the context of the cause and effect analysis are somewhat acceptable from the point of view of individual experience. The idea that the order of time is based on a flow of causally ordered relationships was enunciated by Leibniz but it does not solve the confusion generated by two concepts: the order and the direction of time. The logical clarification is made by Reichenbach through simple examples from mechanical physics: throwing a ball from point A to point B and vice versa as can be seen in Figure 2. The physical process underlying these throwings is a reversible physical process, throwing in a sense is possible in a positive time and in the other way in a negative time.

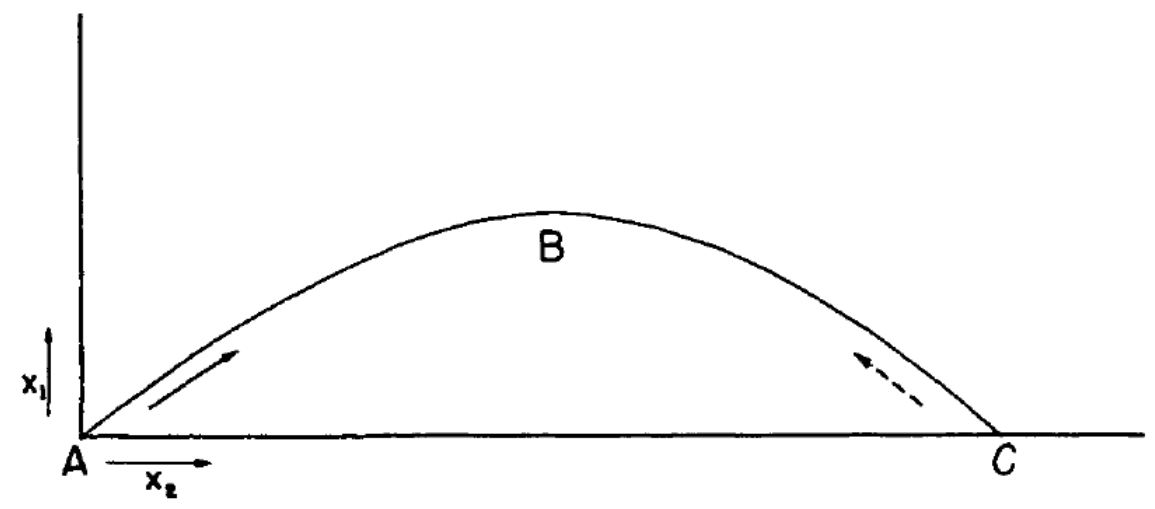

Fig 2. Throwing a ball in two directions

Source: Reichenbach, M. (1971)

Based on mathematical calculation, provided by Reichenbach, M. (1971), throwing a ball is a reversible process". The observation that can be made here and is important for the purpose of this paper is that reversible processes define an order of time (based on unidirectional causality) but not a direction of time. Of course a different approach might be taken into consideration for thermodynamics processes.

Taking into account the above, we will try to transpose the analysed risk into the elements of the dynamic logic of the contradiction.

$\mathrm{e}_{\mathrm{A}}$ - the data are corrupted

$\neg e_{A}$ - the data are not corrupted

ep - the data will be corrupted

ᄀep - the data will not be corrupted

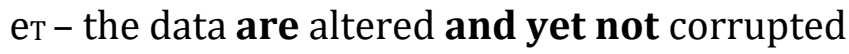

$\neg$ - - the data are not altered and yet are corrupted

Daily practice in the assessment of such a risk coming from the IT area using the RCSA method indicates that each of the above-mentioned alternatives can be recorded as having a probability of occurrence. What further brings the dynamic logic of the contradiction is that all these statements can be true for one observation. The way these observations can be analyzed is further proposed and graphically represented in Figure 3. 


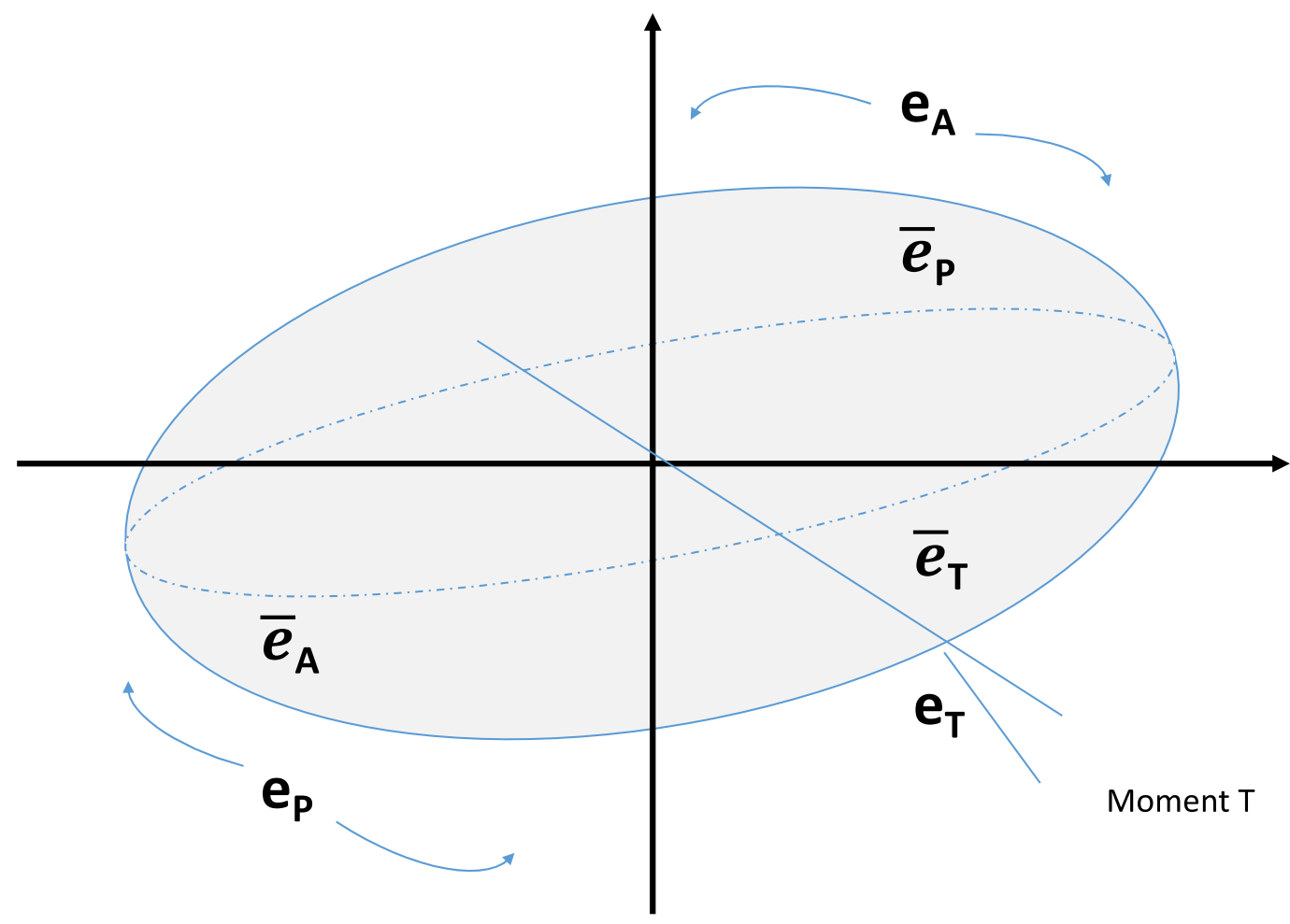

PICBE |

Figure 3. Graphical representation of all possible states in the dynamic logic of the contradictory.

Source: Authors' own research

Data corruption is a reversible process according to the experiences of most users, especially in cases where the data are or can be recovered, it results that in those cases, the time of measurement can be assimilated to the state of $\mathrm{e}_{\mathrm{T}}$, and $\neg \mathrm{e}_{\mathrm{T}}$. Transposing this premise into the logical quantum leads to the following result:

$$
\left.\left.\left.\mathrm{Q}=\mathrm{f}\left[\left(\mathrm{e}_{\mathrm{A}} \times\right\urcorner \mathrm{e}_{\mathrm{P}}\right) \cup\left(\neg \mathrm{e}_{\mathrm{A}} \times \mathrm{e}_{\mathrm{P}}\right) \cup\left(\mathrm{e}_{\mathrm{T}} \times \neg \mathrm{e}_{\mathrm{T}}\right)\right]=\left(\mathrm{e}_{\mathrm{A}} \supset\right\urcorner \mathrm{e}_{\mathrm{P}}\right) \cup\left(\neg \mathrm{e}_{\mathrm{A}} \supset \mathrm{e}_{\mathrm{P}}\right) \cup\left(\mathrm{e}_{\mathrm{T}} \supset\right\urcorner \mathrm{e}_{\mathrm{T}}\right)
$$

Assuming the solution of the logic quant by phases and trying a graphical representation Figure 4 subsequently through the Venn diagrams results:

$$
\mathrm{Q}=\neg \mathrm{ePU} \text { epU }\urcorner \mathrm{eT}
$$

$\mathrm{Q}=$ the data will not be altered $U$ the data will be altered the $U$ data are not altered and yet corrupted

\section{Results and discussions}

The obtained result falls within the transdisciplinary vision of life-level analysis described by Ertas, A. (2018), where ᄀep și ep remain under the influence of a hidden third party which is ᄀет. 


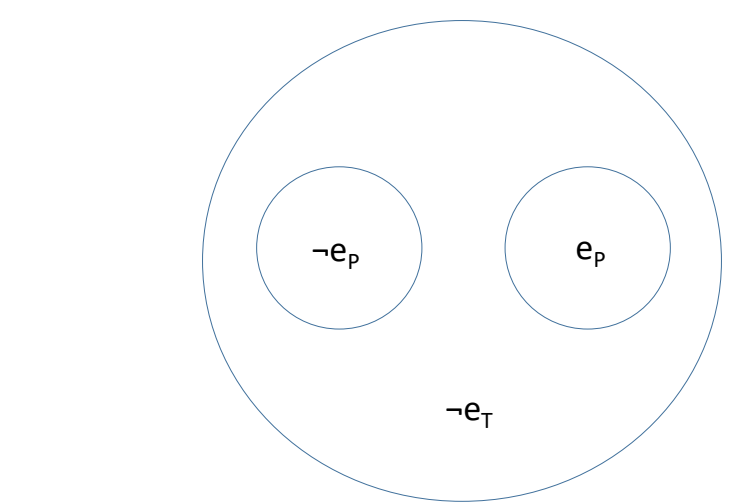

PICBE |

Figure 4. Transdisciplinary vision of life-level analysis Source: Ertas, A. (2018)

In particular, the risk recording model may lead to three distinct recordings with a $100 \%$ probability. Assigning a probability to one or other of the states may be the subject of a new research through which the distribution curves should be tested on a real-time data portfolio following this methodology.

\section{Conclusions}

It makes sense to continue using binary logic only in the absence of irreversible processes! In the case of reversible processes, the order and the direction of time, as understood by common perception, disappear, and the logic of the included middle becomes the main element of identification and understanding of causal relationships, as well as in the way a risk can be fully, rigorously and consistently understood and assessed

\section{References}

Badea D., Tudor R., (2016), Operational risk assessment with Bayesian beliefs networks successful application in other industries. New approaches that could fit Solvency 2, Retrieved February 09, 2017, from http://www.ectap.ro/supliment/internationalfinance-and-banking-conference-fi-ba-2016-xivth-edition/26/.

Birkhoff, G., \& Von Neumann, J. (1936). The Logic of Quantum Mechanics. Annals of Mathematics, 37(4), second series, 823-843. doi:10.2307/1968621

Brenner, J. E. (2010). The philosophical logic of Stéphane Lupasco (1900-1988). Logic and Logical Philosophy, 19(3). doi:10.12775/llp.2010.009

Cushing, J. T. (2007). Philosophical concepts in physics: The historical relation between philosophy and scientific theories. Cambridge: International Society for Science and Religion.

Delegated Regulation (Delegated Regulation (EU) 2015/35

Dumitriu, A., \& Stíhi, T. (1971). Logica polivalentă. Editie nouă, complet refăcută si adăugită de autor cu colaborarea lui Teodor Stíhi. Bucuresti: Editura enciclopedieă română.

EIOPA. (2015, September 14). Guidelines on Own Risk Solvency Assessment (ORSA). Retrieved February 25, 2019, from https://eiopa.europa.eu/GuidelinesSII/EIOPA_Guidelines_on_ORSA_EN.pdf 
Ertas, A. (2018). Transdisciplinary engineering design process. Hoboken, NJ: John Wiley \& Sons.

Institute of Operational Risk, Operational Risk Sound Practice Guidance, Risk Control Self Assessment (RCSA), March 2010

Kahneman, D., \& Tversky, A. (2000). Choices, values, and frames. New York: Russell sage Foundation.

Legea nr. 237/ 2015 privind autorizarea și supravegherea activității de asigurare și

PICBE |

1215 reasigurare

Norma nr. 4/2018 privind gestionarea riscurilor operaționale generate de sistemele informatice utilizate de entitățile autorizate/avizate/înregistrate, reglementate şi/sau supravegheate de către ASF, RO, ASF. (2018, March 19) Retrieved February 25, 2019 from https://asfromania.ro/legislatie/legislatie/6278-norma-nr-4-2018privind-gestionarea-riscurilor-operationale-generate-de-sistemele-informaticeutilizate-de-entitatile-autorizate-avizate-inregistrate-reglementate-si-sausupravegheate-de-catre-autoritatea-de-supraveghere-financiara

Lindley, D. (2008). Uncertainty: Einstein, Heisenberg, Bohr, and the struggle for the soul of science. New York: Anchor Books.

Lupasco, S., 1935, Du devenir logique et de l'affectivité; Vol. 1: Le dualismeantagoniste; Vol.

2: Essai d'une nouvelle théorie de la connaissance, Paris: Vrin; 2nd edition 1973.

Lupasco, S., 1947, Logique et contradiction, Paris: Presses Universitaires de France.

Lupasco, S., 1951, Le principe d'antagonisme et la logique de l'énergie, Paris: Éditions Hermann. 2nd edition Paris: Éditions du Rocher, 1987.

Lupaşcu, Ș, Noica, C., \& Sporici, V. (1982). Logica dinamica a contradictoriului. București: Editura Politică.

Morgan, S. 2015 Scientists show future events decide what happens in the past Retrieved February 27, 2019, from http://www.digitaljournal.com/science/experimentshows-future-events-decide-what-happens-in-thepast/article/434829\#ixzz5gjpIqyOv http://www.digitaljournal.com/science/experiment-shows-future-events-decidewhat-happens-in-the-past/article/434829\#ixzz5gjoRBq7z

Potorac, A. D. (2002). Bazele proiectării circuitelor numerice. București: Matrix Rom. Reichenbach, M. (1971). The Direction of Time.

Slovic, P. \& Weber, E. (2002). Perception of Risk Posed by Extreme Events. Science. Retrieved February 25, 2019 from https://www.researchgate.net/publication/209805350_Perception_of_Risk_Posed_b y_Extreme_Events

Solvency II Directive (Directive 2009/138/EC [recast])

Tudor, R., \& Badea, D. (2017). Operational risk quantification and modelling within Romanian insurance industry. Proceedings of the International Conference on Business Excellence,11(1), 637-648. doi:10.1515/picbe-2017-0068

Wheeler's delayed-choice gedanken experiment with a single atom (2015). Retrieved February 27, 2019, from http://www.nature.com/articles/nphys3343; https://doi.org/10.1038/nphys3343 